\title{
First record of brown long-eared bat Plecotus auritus (Chiroptera: Vespertilionidae) for Sicily island (Italy)
}

\author{
Antonio Fulco ${ }^{1,2}$, Ivy Di Salvo ${ }^{1,2}$, Danilo Russo $^{2} \&$ Mario Lo Valvo ${ }^{1 *}$
}

\begin{abstract}
${ }^{1}$ Dipartimento di Scienze e Tecnologie Biologiche, Chimiche e Farmaceutiche, Laboratorio di Zoologia applicata University of Palermo, Via Archirafi 18, I-90123 Palermo (Italy).

${ }^{2}$ Wildlife Research Unit, Laboratorio di Ecologia Applicata, Sezione di Biologia e Protezione dei Sistemi Agrari e Forestali, Dipartimento di Agraria. University of Naples “Federico II", Via Università 100, I-80055 Portici, Napoli (Italy).

*Corresponding author e-mail: mario.lovalvo@unipa.it
\end{abstract}

DOI: http://dx.doi.org/10.14709/BarbJ.8.1.2015.07 (C) 2015 Published by SECEMU.

Spanish title: Primera observación del murciélago orejudo dorado (Chiroptera: Vespertilionidae) en la isla de Sicília (Itália)

The knowledge of the bat fauna of Sicily (Southern Italy) is scarce, fragmentary or sometimes even confusing (Di Salvo et al. 2012b). Although for other groups of terrestrial vertebrates on the island a detailed checklist is available, this is not the case of bats, due to insufficient research effort and the typical difficulties of detecting and identifying these elusive mammals (Russo et al. 2004).

A recent review by Agnelli et al. (2008) mentioned 20 species for the region, and a few more were added by further investigations, namely the Bechstein's bat (Myotis bechsteinii Kuhl, 1817) (Di Salvo et al. 2012a), the soprano pipistrelle (Pipistrellus pygmaeus Leach, 1825) (Fichera et al. 2013) and the Maghreb mouse-eared bat (Myotis punicus Felten, 1977) (Bogdanowicz et al. 2015). The occurrence of Hypsugo cfr. darwinii - still awaiting morphological description - has also been confirmed (Veith et al. 2011).

It is likely that the checklist of bats of Sicily is still far from being exhaustive. The large surface, the geographical position and the variety of habitats on the island, along with the good habitat quality still persisting in many areas are all factors providing potential niches to species occurring in the nearby Italian peninsula but not yet found in Sicily. Among the potentially overlooked species, several are forest bats, the most elusive and least investigated bat guild occurring in the region.

To help fill this gap, in the past few years specific studies were carried out on the distribution of bat species in Sicily, especially in the woodlands of the Nebrodi Mountains, home to large forests including old growth stands of Turkey oaks (Quercus cerris), beeches (Fagus sylvatica) and European yews (Taxus baccata), as well as wetlands (lakes Maulazzo and Biviere). Thirteen bat species have been reported for the territory of the Nebrodi Regional Park (Zava \& Violani 1992, Di Salvo et al. 2012a, 2012b, Mucedda et al. 2012).

On 12th September 2014 we surveyed a beech forest in the municipality of Caronia (Messina province) by erecting two mistnets ( 6 and $12 \mathrm{~m}$, mesh size $=14 \mathrm{~mm}$ ) at a drinking site at $1,500 \mathrm{~m}$ a.s.1. We captured a young female brown longeared bat Plecotus auritus (Linneaus, 1758) (Fig. 1), that was identified following Dietz \& Helversen (2004), while sex and age class were ascertained following Anthony (1988) and Racey (1988). The main biometric measures taken from the specimen were as follows: forearm length $=38.3 \mathrm{~mm}$; thumb $=6.5 \mathrm{~mm}$; claw $=2.5 \mathrm{~mm}$; weight $6.65 \mathrm{~g}$.

The capture of $P$. auritus, apparently widespread in Italy but occurring at low density whose presumed rarity in Italy (Lanza 2012), represents an interesting biogeographical record, as this bat is mostly known for the north and centre of the Italian peninsula (Lanza \& Agnelli 1999, Agnelli et al. 2004, Lanza 2012); large gaps in the knowledge of the species distribution still occur for the rest of the country (Lanza \& Agnelli 1999, Agnelli et al. 2004, Lanza 2012). In the nineteenth century Sanvicente (1849) reported on the presence of Vespertilio auritus (ancient synonym for $P$. auritus) on the island of Lampedusa (off the southern coast of Sicily) but the reliability of this record has been questioned (Massetti \& Zava 2002 in Lanza 2012). Moreover, Galvagni 


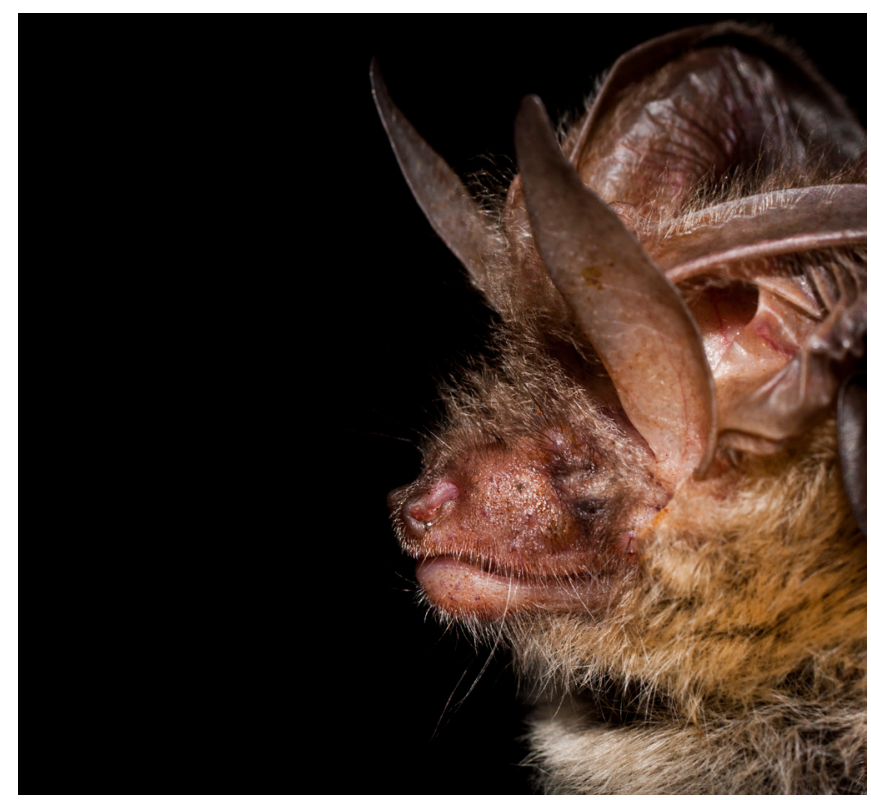

Fig. 1 - Close-up of the Plecotus auritus specimen captured in the Nebrodi Mountains (Sicily)

(1837) mentioned P. auritus in Sicily for fMt. Etna (Nicolosi) and Minà Palumbo for the Madonie Mountains, Palermo, Cefalù, Castrogiovanni (today called Enna) and Agrigento.

However, Sarà (1999), following Kock (1969) and Felten and Storch (1970) attributed such findings to P. austriacus, known to occur in Sicily, since its distinction from the sibling P. auritus dates back to the mid 1950s' (Topal 1958 in Lanza 1959) so previous records of this species were obviously attributed to $P$. auritus. For this reason, further reviews (Agnelli et al. 2004, 2008, Angelici et al. 2009, Lanza 2012) omitted $P$. auritus from the bat fauna of Sicily and its minor islands. Based on our observation we cannot rule out that some of the old records were actually correctly referred to $P$. auritus. P. auritus is listed as "near threatened"" (NT) in Italy (Rondinini et al. 2013); the species is also included in Annex IV of the 92/43/EC Habitats Directive. The major threat to this species is given by intensive forestry (Rondinini et al. 2013).

Further information is needed on the distribution and ecology of $P$. auritus in Sicily to assess its conservation status and develop appropriate conservation plans.

\section{ACKNOWLEDGEMENTS}

We wish to thank Stefania D'Arpa for her support in the field work. Funding was provided by the "Dipartimento Interventi Strutturali per l'Agricoltura della Regione Siciliana" in the framework of the "Sviluppo di strumenti gestionali propedeutici alla pianificazione Faunisticovenatoria ed ambientale e alla Conservazione delle specie minacciate della Regione Siciliana" project. Capture permits were issued by the "Ministero dell'Ambiente e della Tutela del Territorio e del Mare-Direzione Protezione Natura (Prot. 0042847/PNM of 9 Aug 2013, Div. II)".

We also thank three anonymous reviewers for their valuable comments on a first manuscript draft.

\section{REFERENCES}

Agnelli, P., Di Salvo, I., Russo, D. \& Sarà, M. 2008. Chirotterofauna della Sicilia. In: AA.VV. Atlante della Biodiversità della Sicilia: Vertebrati terrestri. Studi e Ricerche, 6. Palermo: Arpa Sicilia.

Agnelli, P., Martinoli, A., Petriarca, E., Russo, D., Scaravelli, D. \& Genovesi, P. 2004. Linee guida per il monitoraggio dei Chirotteri: indicazioni metodologiche per lo studio e la conservazione dei pipistrelli in Italia. Istituto Nazionale per la Fauna Selvatica "Alessandro Ghigi”, Ministero dell'Ambiente e della Tutela del Territorio. Quaderni di Conservazione della Natura $n^{\circ} 19$.

Angelici, F.M., LAurenti, A. \& NAPPI, A. 2009. A checklist of the mammals of small italian island. Hystrix, the Italian Journal of Mammology 20: 3-27. Doi:_http:// dx.doi.org/10.4404/hystrix-20.1-4429

Anthony, E.L.P. 1988. Age determination in bats: In: Kunz, T. H. (Ed.), Ecological and Behavioral Methods for the Study of Bats. Smithsonian Institution Press, Washington D. C. and London: 47-58.

Bogdanowicz, W., Hulva, P., Černá Bolfíková, B., Buś, M. M., Rychlicka, E., Sztencel-JabŁonKa, A., Cistrone, L. and Russo, D. (2015), Cryptic diversity of Italian bats and the role of the Apennine refugium in the phylogeography of the western Palaearctic. Zoological Journal of the Linnean Society. doi: 10.1111/zoj.12248. Doi: http://dx.doi. org/10.1111/zoj.12248

Di Salvo, I., Fulco, A., Sarà, M. \& Russo, D. $2012 \mathrm{a}$. Occurrence of Bechstein's bat Myotis bechsteinii (Chiroptera: Vespertilionidae) in Sicily. Natura Rerum 1: 75-78.

Di Salvo, I., Fulco, A. \& Sarà, M. 2012b. New records on woodland bats in the nebrodi regional park. Hystrix, the Italian Journal of Mammology, (n.s.) Supp.: 115.

Dietz, C. \& Helversen (von), O. 2004. Illustrated identification key to the bats of Europe - Electronic publication, Version 1.0.

Felten, H. \& Storch, G. 1970. Kleinsauger von den italienischen Mittelmeer Inseln Pantelleria und Lampedusa. Senkenbergiana Biologica51: 159-173.

Fichera, G., Mucedda, M., Catalano, P. \& Pidinchedda, E. 2013. Firs record of Pipistrellus pygmaeus in Sicily. Biodiversity Journal 4: 467-470.

Galvagni, G.A. 1837. Fauna etnea ossia materiali per la compilazione della zoologia dell'Etna. Atti Accademia Gioenia di Scienze Naturali in Catania, Catania.

Kock, D. 1969. Die Fledermaus-Fauna des Sudan. Abhandlungen der Senckenbergischen Naturforschenden Gesellschaft 521: 1-238. 
Lanza, B. 1959. Chiroptera. In: Toschi, A., Lanza, B., (eds.). Fauna d'Italia, Vol. IV, Mammalia. Bologna: Calderini, 187-473.

LANZA, B. 2012. Chiroptera - Fauna d'Italia - Vol. XLVII Mammalia V. Bologna: Calderini.

Lanza, B. \& Agnelli, P. 1999. Chirotteri, Chiroptera Blumenbach, 1779. In: Spagnesi, M. \& Toso, S. (eds.), pls by Catalano, U. Iconografia dei Mammiferi d'Italia. Ministero dell'Ambiente, Servizio Conservazione Natura - Istituto Nazionale per la Fauna Selvatica “Alessandro Ghigi”, Roma e Ozzano dell’Emilia (Bologna).

Mucedda, M., Fichera, G. \& Pidinchedda, E. 2012. Record of Barbastella barbastellus in Sicily after 56 years. Natura Rerum 1: 79-81.

RACEY, P.A. 1988. Reproductive assessment in bats. In: Kunz, T.H, (Ed.). Ecological and behavioral methods for the study of bats. Smithsonian Institution Press, Washington D.C. and London: 31-45.

Rondinini, C., Battistoni, A., Peronace, V., Teofili, C. (compilatori). 2013. Lista Rossa IUCN dei Vertebrati Italiani. Comitato Italiano IUCN e Ministero dell'Ambiente e della Tutela del Territorio e del Mare, Roma.
Russo, D., Cistrone, L., Jones, G. \& Mazzoleni, S. 2004. Roost selection by barbastelle bats (Barbastella barbastellus, Chiroptera: Vespertilionidae) in beech woodlands of central Italy: consequences for conservation. Biological Conservation 117: 73-81. Doi: http://dx.doi.org/10.1016/S00063207(03)00266-0

SANVISENTE, B. 1849. L'isola di Lampedusa eretta a colonia dal munificentissimo nostro Sovrano Ferdinando II, descritta dal Cav. B. Sanvisente capitano di fregata e governatore della medesima. Con un cenno sulle minori isole Linosa e Lampione. Regia tipografica Militare; Napoli.

SARÀ, M. 1999. Il catalogo dei mammiferi della Sicilia rivisitato. In Sarà M. ( $3^{\circ}$ ed.), Minà Palumbo F., 1866-67, 1868. Catalogo dei mammiferi della Sicilia. Società Messinese di Storia Patria, XVII.

Veith, M., Mucedda, M., Kiefer, A. \& Pidinchedda, E. 2011. On the presence of pipistrelle bats (Pipistrellus and Hypsugo; Chiroptera: Vespertilionidae) in Sardinia. Acta Chiropterologica 13: 89-99. Doi: http://dx.doi.org/10.3161/150811011X578642

ZaVA, B. \& Violani, C. 1992. Nuovi dati sulla chirotterofauna italiana. Bollettino del Museo Regionale di Scienze Naturali, Torino 10: 261-264. 